do czynienia $\mathrm{z}$ innym rodzajem łączenia różnych typów $\mathrm{i}$ aspektów podróży. Wspomniano już o tym wyżej - mianowicie ta sama podróż podejmowana przez kilka osób, miała dla każdej z nich inny charakter. Centralną osobą był naturalnie szlachcic lub magnat, w jego interesie podróż podejmowano i cała była jemu podporządkowana. $\mathrm{Z}$ jego punktu widzenia mogła ona mieć charakter podróży edukacyjnej szeroko rozumianej, uwzględniającej również aspekty podróży naukowej. Młodzieniec słuchał wykładów uniwersyteckich, ale przede wszystkim korzystał $\mathrm{z}$ innego aspektu podróży - poznawał, zwiedzał, brał prywatne lekcje z różnych nauk itp. Jego preceptor natomiast, obok swoich obowiązków polegających na czuwaniu nad powierzonym mu młodzieńcem, wpisywał się na uniwersytet i poszerzał $w$ ten sposób swoją wiedzę, niekiedy zdobywając stopnie naukowe - dla niego była to więc głównie podróż naukowa.

Innym przypadkiem jest wzajemne uzupełnianie się tych podróży. Młody człowiek najpierw wyjeżdżał za granicę, by uczyć się w którejś z tamtejszych szkół. Potem na jakiś czas powracał do domu i po kilku latach wyjeżdżał ponownie, tym razem już w podróż edukacyjną. Takie łączenie różnych podróży polecała staropolska teoria pedagogiczna. Na przykład Hieronim Baliński w traktacie „De educatione pueri” zalecał by młodzieńca dwa razy wysłać do cudzych krajów. Gdy skończy dwanaście lat, po raz pierwszy, na dwa albo trzy lata. Baliński polecał ziemie niemieckie, chociaż dostrzegał ich wady - „wszystko w Niemczech przygrubszym (prymitywne, prostackie), ale ... potem się to we Włoszech wypoleruje". Przerwa w podróży powinna trwać okolo roku, w trakcie którego młody człowiek miał poznawać polskie prawa - „leges patrias dać mu w ręce i już wczas mu informacyje gotować i informować go, ile będzie przez ten czas mogło być w nich, ne sit hospes in patria (aby nie był obcym w ojczyźnie)", przypatrywać się obradom sejmu - „przy kim przypatrując i przysłuchując ludziom, zwyczajom, rzeczom i sprawom, gdyż też tam legum executia bywa", poznawać dwór. Około piętnastego roku życia powinien ponownie wyjechać. Tym razem celem mają być Włochy, miał tam być dwa lata „aby i pierwsze studia przepolerował i exercitia graviora capescat, których tam wszytkich barzo dobrze uczą, jako kawalkatury, szermierstwa, skoków, muzyki, turniejów ze wszytkich miar i broni, na koniu jako której używać"?.

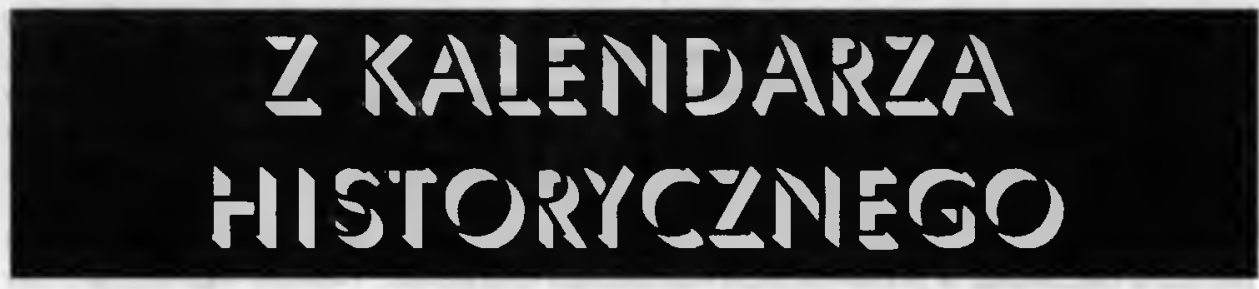

Wiesław Jamrożek

Poznań

\title{
Uniwersytet Wakacyjny w Zakopanem
}

W bieżącym roku kalendarzowym mija 90 lat od uruchomienia w Zakopanem Wyższych Kursów Wakacyjnych, zwanych również Uniwersytetem Wakacyjnym. Myśl powolania do życia adrębnego stowarzyszenia, którego zadaniem miało być utworzenie instytucji - jak to później

'H. Baliniski, De educatione pueri nobilis, w: Pisma pedagngiczne polkkiego Odrodzenia, oprac. J. Skoczek, Wroclaw 1956, s $374 \mathrm{i}$. 
określono w odezwie z marca 1904 r. - o charakterze uniwersyteckim zrodziła się jeszcze w 1903 roku w środowisku działaczy oświatowych związanych z Towarzystwem Uniwersytetu Ludowego i mniej lub bardziej bliskich polskiej socjaldemokracji.

Przed planowaną instytucją wytyczono jako główny cel ,,podniesienie poziomu wiedzy i myśli krytycznej w społeczeństwie polskim za pomocą szeregu wykładów, mających nie tylko zaznajamiać $z$ ostatnimi zdobyczami nauki, lecz w pierwszym rzędzie - przez zapoznawanie $\mathrm{z}$ metodami badań naukowych oraz przez filozoficzne traktowanie każdego, pobudzać słuchaczy do samodzielnych prac $\mathrm{i}$ badań, pomóc im w wyrabianiu sobie śwjatopoglądu i w rezultacie stworzyć atmosferę, w której dojrzewają umysly wolne"!.

W czasie dyskusji nad kształtem organizacyjnym Towarzystwa i jego Uniwersytetu Wakacyjnego oraz w dalszym programowaniu ich pracy korzystano m.in. ze wzorów wolnego uniwersytetu wakacyjnego w Salzburgu, wolnego uniwersytetu rosyjskiego Maksyma Kowalewskiego w Paryżu, Uniwersytetu Nowego w Brukseli, Szkoły Nauk Ekonomicznych i Politycanych w Londynie ${ }^{2}$. Wskazywał na ten fakt m.in. współautor polskiej koncepcji wolnego uniwersytetu wakacyjnego, Kazimierz Kelles-Krauz (były wykładowca Université Nouvelle de Bruxelles, gdzie uzyskal nawet tytuł doktora nauk społecznych), ustosunkowując się jednak dość krytycznie do wymienionego uniwersytetu wakacyjnego w Salzburgu. Pisał: „wykładają tam wyłącznie profesorowie i docenci niemieckich uniwersytetów przedmioty wyłącznie objęte programem uniwersyteckim i cała rzecz ma za cel być tylko periodyczną demonstracją za wznowieniem w Salzburgu dawnego uniwersytetu rządowego, a przeciw założeniu tam wolnego uniwersytetu katolickiego, za którym agitują klerykali Rzeszy i Austrii" 3 .

Cytowany K. Kelles-Krauz przedstawiając istote „uniwersytetu wolnego" (którym miał być właśnie Uniwersytet Wakacyjny w Zakopanem) wskazywał, że nie udziela on dyplomów, "nie kształci młodzieży na fachowców”, że tworzony, utrzymywany i kierowany jest przez grupy osób prywatnych a nie przez rząd (choć do koncepcji „uniwersytetu wolnego" zbliżone jest również rządowe Collège de France), "nie pyta ani swych profesorów, ani shuchaczy o żadne dyplomy ani stopnie naukowe", pozostawia wykladowcom swobodę w prowadzeniu swego kursu, a przede wszystkim „oddając się wyłącznie w służbę czystej myśli, petni tylko czynność podniecania umysłowości społecznej, dawania podniety i inicjatywy w sprawach nauki $i$ bytu społecznego - lecz zawsze za pomocą i w granicach nauki". „Kwintesencją uniwersytetu wolnego - pisał dalej - jest być przytułkiem i rozsadnikiem wszelkiej myśli wolnej, o ile dorosła ona do formy naukowej $i$ w nią się przyodziała"4.

W porównaniu $z$ koncepcją uniwersytetu ludowego realizowaną w TUL kursy odbywane w ramach Wolnego Uniwersytetu Wakacyjnego ,różniły się swym wyższym poziomem, prezentując wykłady na poziomie uniwersyteckim - ze zwróceniem uwagi na metodologię danych nauk oraz ich rolę w procesie poznania". Ważnym celem tych kursów było również zapewnienie łączności pomiędzy „rozproszonymi w różnych dzielnicach Polski i za granicą przedstawicielami nauki zarówno ze sobą, jak i z szerokimi kręgami słuchaczy", stworzenie niektórym wybitnym badaczom własnego miejsca pracy pedagogicznej, którego byli dotąd pozbawieni, dostarczenia słuchaczom możności otrzymania wskazówek i materiałów do późniejszej pracy w ciaggu rokus.

\footnotetext{
' Archiwum Akt Nowych w Warszawie (AAN), Odezwa TWKW z marca 1904 r., Archiwum PPS, Dzial PPSD, syg. $305 / \mathrm{V} / 14$

${ }^{2}$ J. Myśliniski, Uniwersytet Wakacyjny w Zakopanem w r. 1904 (Towarzystwo Wyisszych Kursów Wakacyjnych), Przegląd Historyczno-Oświatowy 1963, nr 1, s. 8-9.

${ }^{3}$ Zob. K. Krauz. Wolny polski uniwersytet wakacyjny, Krytyka 1904, t. I, z 6, s. $455-459$.

1 Tamże, s. $460-461,463$.

'W. Bieńkowski, Kaximierz Kelles-Krauz. Zycie i dzielo, Wrocław 1969, s. $292-293$.
} 
Wybór miesięcy wakacyjnych na termin kursów Uniwersytetu Wakacyjnego i Zakopanego na ich miejsce nie były dziełem przypadku. K. Kelles-Krauz wyjaśniał: „Towarzystwo Wyższych Kursów Wakacyjnych pragnie, żeby jego «uniwersytet wolny», bez względu na to, jaka będzie absolutna ilość jego słuchaczy, promieniował o ile możności równomiernie na całą Polskę. Dlatego działalność jego została ograniczona do kilku tygodni wakacyjnych, a miejsce obrano takie, które ktoś przesadnie wprawdzie nazwal «letnią stolicą Polski», ale które w każdym razie ściąga niezaprzeczenie liczne zastępy inteligencji ze wszystkich dzielnic naszej ojczyzny" ".

Na początku 1904 r. zatwierdzony zostal statut Towarzystwa Wyższych Kursów Wakacyjnych i w lutym tego roku mogło odbyć się walne zgromadzenie, na którym wybrano Zarząd. Przewodniczącym został Odo Bujwid, zastępcą przewodniczącego - Wilhelm Feldman, sekretarzami - Kazimierz Kelles-Krauz i Ignacy Wasserberg, skarbnikiem - Emil Bobrowski. W skład Zarządu weszli ponadto: Z. Daszyńska-Golińska, Konstanty Krzeczkowski, Ludwik Rajchman i Wackaw Werner ${ }^{7}$.

Uroczyste rozpoczęcie pierwszego cyklu wykładów odbyło się 31 lipca 1904 roku. Wykład inauguracyjny „O celach i zadaniach wolnych uniwersytetów” wygłosił K. Kelles-Krauz. W wykładach w 1904 roku uczestniczyło w sumie 456 shuchaczy (aż 54\% grona słuchaczy stanowiły kobiety). Do grona prelegentów należeli m.in. wspomniany już K. Kelles-Krauz (który w pierwszej serii wykładów miał jeszcze prelekcje i konwersatorium nt. „Nowoczesny ruch społeczny jako drugie odrodzenie"), W. Feldman, K. Twardowski, B. Limanowski, K. Mokłowski, A. Mahrburg, L. Krzywicki, Z. Daszyńska-Golińska ${ }^{8}$.

Frekwencja w następnym roku - ze względu na sytuację polityczną w Królestwie Polskim - wyraźnie się zmniejszyła (do 339). Tym razem w roli prelegenta inaugurującego wykłady wystąpił - w miejsce zmarłego w czerwcu K. Kelles-Krauza - W. Feldman. Wśród prelegentów znaleźli się również - nie wspomniani powyżej - Stanisław Karpowicz, Stanisław Brzozowski, Witold Jodko $\mathrm{i}$ inni.

W porównaniu z rokiem ubiegłym udział poszczególnych dziedzin wiedzy nie uległ zasadniczej zmianie i był następujący: nauki przyrodnicze i filozoficzne w $1904-47 \%$, w 1905 - 41\%; nauki społeczne w $1904-19 \%$, w 1905 - 21\%; nauki historyczne w $1904-14 \%$, w $1905-13 \%$; nauki literackie w $1904-20 \%$, w $1905-25 \%$.

W kolejnym roku kursy nie zostały już wznowione. Zadecydowała o tym z pewnością sytuacja w Królestwie Polskim, jak i śmierć jednego z głównych inicjatorów omawianego przedsięwzięcia - Kazimierza Kelles-Krauza ${ }^{10}$.

Uniwersytet Wakacyjny nie posiadal wprawdzie partyjnego charakteru, to jednak $w$ jego narodzinach, jak i funkcjonowaniu zasadniczą rolę odgrywali socjalni demokraci, zwłaszcza z PPS i galicyjskiej PPSD (bądź też inni działacze bardzo bliscy temu obozowi). Także i wśród shuchaczy ton nadawali i liczebnie przeważali uczestnicy o orientacji socjalistycznej". Działacze TWKW usiłowali zarazem podkreślić ponadpartyjny charakter kursów i odpierać zarzuty, jakoby Uniwersytet był „kuźnicą socjalistyczną"12.

\footnotetext{
- K. Krauz, Wolny polski uniwersytet wakacyjiny..., s. 460

7 Sprawozdanie Zarzqdu (TWKW) z czynnosci ad 1 patdziemika 1903 do 30 sierpnia 1904 raku, Kraków 1904, s. 3.

- Tamże, s. $10-12$.

- Sprawozdanie Zarzqdu (TWKW) z czynnosci od 30 sierpnia 1904 roku do 25 sierpnia 1905 roku, Kraków 1905, s. $12-16$.

10 Por. R. Terlecki, Otwiata doroslych i popularyzacja namki w Galicji w okresie autonomii, Wroclaw 1990, s. 183.

11 A. Światlo, Otwiata a polski ruch robotniczy 1876-1939, Warszawa 1981, s. 205.

12 W. Feldman, W sprowie zakopianskiego Uniwersytefu Wakacyjnego, Naprzód 1904, nr 259, s. 2; P. Margor, Pierwszy rok uniwersyletu zakopiańskiego, Krytykn 1904, I. I, z. 10, s. $240-241$.
} 